\title{
A Case Associating an Erosive Pustular Dermatosis of the Legs and Scalp
}

\author{
Marie Jourdan ${ }^{\mathrm{a}}$ Guillaume Chaby $^{\mathrm{a}}$ Lilia Meziane $^{\mathrm{a}}$ \\ Jean-Philippe Arnault ${ }^{a}$ Denis Chatelain ${ }^{b}$ Catherine Lok $^{a}$ \\ Departments of ${ }^{a}$ Dermatology and ${ }^{b}$ Anatomopathology, University Hospital of \\ Amiens, Amiens, France
}

\section{Key Words}

Erosive pustular dermatosis · Spongiform pustules · Skin atrophy

\begin{abstract}
Erosive pustular dermatosis (EPD) of the legs and the scalp have been described as two separate entities occurring in a different context. We report the original case of a patient with an EPD of both the scalp and legs.
\end{abstract}

\section{Case Report}

An 83-year-old Caucasian woman was hospitalized in our department of dermatology with a presentation of crusted erosions of the lower limbs and scalp. She suffered from a chronic venous insufficiency and mixed ulcers of the lower limbs with failure of two attempts to skin graft ten years ago. Examination showed superficial and rounded crusted erosions associated with multiple pustules reaching the lower third of the legs ( fig. 1 ), scars of donor sites of grafts on thighs and part of the scalp ( fig. 2).

Laboratory investigations disclosed a moderate inflammatory syndrome with an elevated Creactive protein $31 \mathrm{mg} / \mathrm{l}(<5 \mathrm{mg} / \mathrm{l})$, hyperleukocytosis at $14,000 / \mathrm{mm}^{3}$; electrolytes, glucose blood level, renal and hepatic tests were normal. Staphylococcus aureus was found in cultures from ulcer swabs. Light microscopy revealed a polymorphous inflammatory infiltrate of the dermis, rich in neutrophils, coming together in the epidermis in subcorneal spongiform pustules (fig. 3 ). Direct immunofluorescence was negative.

In view of this clinical picture and the histological finding, we excluded pustular psoriasis, epidermolysis bullosa, bullous pemphigoid, pyoderma gangrenosum, kerion, and suggested an erosive pustular dermatosis (EPD) of leg and scalp especially as antistaphylococcal antibiotics proved ineffective and the evolution was favorable with oral zinc supplementation and application of topical corticosteroids (betamethasone) until disappearance of the lesions. 


\section{Discussion}

Two types of EPD are discussed in the literature: one on the legs and the other one on the sclap.

EPD of the leg was first described in 1987 by Lanigan and Cotterill [1]. It has mainly been described as a rare form of sterile pustulosis concerning mostly elderly patients with a long history of venous insufficiency, stasis dermatitis and stasis ulcers, dermatoliposclerosis, cutaneous atrophy, or cardiac failure [2, 3]. The pathophysiology remains unclear but abnormality of neutrophil chemotaxis and/or of production of chemoattractants and cytokine (IL-8) in the skin might be involved [3, 4].

EPD of the scalp is a rare disease first described in 1977 by Burton [5], then mostly reported in elderly patients, predominantly female, who have had prolonged exposure to sunlight $[6,7]$. A local trauma (cryotherapy, topical chemotherapy, laser therapy, electrosurgery, excisional surgery, grafting) is often described as a triggering factor on an atrophic skin, and associations with autoimmune diseases have been reported, even if the causes and pathogenesis still remain uncertain [6-10].

Up to now, only one case of this association has been described in the literature and it fits into the context of autoimmune myasthenia gravis [4].

Laboratory data are usually normal even if sometimes elevated values of inflammation markers (erythrocyte sedimentation rate, C-reactive protein, polyclonal hypergammaglobulinemia) and rarely the presence of various autoantibodies (rheumatoid factor, thyroglobulin, etc.) are described $[9,10]$. In both entities, a histological appearance of spongiform pustules with neutrophils in the epidermis was reported several times [11]. Bacteria and fungi often isolated from the lesions have been considered secondary colonizers rather than the primary cause of infection since anti-infectious agents are not effective, as it was the case with our patient $[1,12]$.

The response to corticosteroids suggests indeed an inflammatory and amicrobic phenomenon and some authors highlight the involvement of local trauma that could trigger cytokine production by keratinocytes particularly in cases of associated autoimmune disease [4]. A zinc deficiency has also been implicated; for other authors, skin atrophy could play a major role [13]. This last hypothesis seems to be supported by our case that showed erosive pustular lesions on elective sites of skin atrophy: scalp heliodermatitis, old skin grafts, donor sites of grafts (table 1).

They are sometimes improved by zinc supplementation and the application of topical corticosteroids has been widely used with a variable and inconstant response, with frequent relapses observed [14]. Moreover, as the prolonged use of topical corticosteroids on atrophic skin may be deleterious, topical tacrolimus has been shown to be effective, and devoid of many side effects of topical corticosteroids such as epidermal atrophy [15]. Systemic steroids have been used more rarely due to a lack of results. Oral nimesulide (non-steroidal anti-inflammatory drug) and isotretinoin have been used effectively in the treatment of EPD [16] (table 2).

Our case is the original observation of an association of an EPD of the legs with an EPD of the scalp, in favor of a pathophysiological mechanism similar between these two entities. We support the theory of an inflammatory phenomenon preponderant in 
atrophic areas, whether due to actinic damages, scars or venous insufficiency. We recover the idea of a similar mechanism through the parallel evolution of the affected sites in our patients and their simultaneous healings.

Table 1. Diagnostic criteria of erosive pustular dermatosis

\begin{tabular}{|c|c|}
\hline Context & $\begin{array}{l}\text { Predilection for women. } \\
\text { Mainly in the elderly. } \\
\text { Possible association with autoimmune disorders (Hashimoto, Takayasu, rheumatoid } \\
\text { arthritis, autoimmune liver diseases, myasthenia gravis, etc.) } \\
\text { EPD of the scalp: Atrophic sun-damaged skin of the scalp; immediately or a long delay } \\
\text { after a triggering factor (local trauma, surgery, cryotherapy, herpes zoster, X-ray therapy, } \\
5 \text {-fluorouracil treatment, etc.). } \\
\text { EPD of the legs: chronic venous insufficiency with stasis dermatitis, stasis ulcers, } \\
\text { cutaneous atrophy, cardiac failure. }\end{array}$ \\
\hline $\begin{array}{l}\text { Clinical } \\
\text { examination }\end{array}$ & $\begin{array}{l}\text { Crusted, pustular and shallow erosive lesions. } \\
\text { Possible scarring alopecia on the scalp. } \\
\text { Most often painless, possible pruritus. } \\
\text { No systemic symptoms. }\end{array}$ \\
\hline Biology & $\begin{array}{l}\text { Normal. } \\
\text { Possible elevated values of markers of inflammation. } \\
\text { Possible positive search for autoantibodies if association with autoimmune disease. }\end{array}$ \\
\hline Ulcer swabs & $\begin{array}{l}\text { Negative. } \\
\text { Secondary colonization of bacteria (Staphylococcus aureus or epidermidis) and/or fungi } \\
\text { (Candida albicans or parapsilosis). }\end{array}$ \\
\hline Histology & $\begin{array}{l}\text { Intraepithelial neutrophilic infiltrate to subcorneal spongiform neutrophil pustules. } \\
\text { Atrophic epidermis with erosions. } \\
\text { Dermis nonspecific inflammatory infiltrate. } \\
\text { Follicular destruction. } \\
\text { No evidence of vasculitis. } \\
\text { Solar degeneration on the scalp (loss of normal dermal collagen architecture, elastosis). } \\
\text { Negative direct immunofluorescence. }\end{array}$ \\
\hline $\begin{array}{l}\text { Differential } \\
\text { diagnosis }\end{array}$ & $\begin{array}{l}\text { Bacterial or fungal infection. } \\
\text { Pyoderma gangrenosum. } \\
\text { EPD of the scalp: folliculitis decalvans, actinic keratosis, squamous cell carcinoma, } \\
\text { pemphigus foliaceus. } \\
\text { EPD of the legs: venous or arterial ulcerations, pustular psoriasis, autoimmune bullous } \\
\text { disease. }\end{array}$ \\
\hline $\begin{array}{l}\text { Response to } \\
\text { treatment }\end{array}$ & $\begin{array}{l}\text { Resistance to local or systemic antibiotics. } \\
\text { Resistance to classic local treatment of ulcers on legs. } \\
\text { Response to topical or systemic steroids. } \\
\text { Possible relapse. }\end{array}$ \\
\hline
\end{tabular}


Table 2. Review of different treatments used for erosive pustular dermatosis in the literature

\begin{tabular}{|c|c|c|c|c|}
\hline Authors & Cases & $\begin{array}{l}\text { Sex/age } \\
\text { years }\end{array}$ & Site & Effective treatment \\
\hline Brouard et al. (2002) [3] & 3 & $\begin{array}{l}2 \mathrm{~F} / 84-91 \\
1 \mathrm{M} / 76\end{array}$ & legs & $\begin{array}{l}\text { Oral methylprednisolone } \\
\text { Betamethasone } \\
\text { Topical tacrolimus } \\
\text { Skin graft }\end{array}$ \\
\hline Sawada et al. (2010) [4] & 1 & $\mathrm{~F} / 70$ & legs and scalp & $\begin{array}{l}\text { Oral methylprednisolone } \\
\text { Topical sulfadiazine silver cream } \\
\text { Clobetasol }\end{array}$ \\
\hline Grattan et al. (1988) [6] & 12 & $\begin{array}{l}7 \mathrm{~F} / 59-90 \\
5 \mathrm{M}\end{array}$ & scalp & $\begin{array}{l}\text { Clobetasol } \\
\text { Combined steroid-antimicrobial preparations } \\
\text { (neomycin-nystatin-hydrocortisone) }\end{array}$ \\
\hline Rongioletti et al. (1999) [7] & 2 & $\begin{array}{l}\mathrm{F} / 78 \\
\mathrm{M} / 83\end{array}$ & scalp & Gentamycin-betamethasone cream \\
\hline Guarneri and Vaccaro (2009) [8] & 1 & M/93 & scalp & $\begin{array}{l}\text { Oral methylprednisolone } \\
\text { Gentamycin-betamethasone cream }\end{array}$ \\
\hline Yamamoto and Furuse (1995) [10] & 1 & $\mathrm{~F} / 87$ & scalp & Topical corticosteroids \\
\hline Pye et al. (1979) [12] & 6 & $\mathrm{~F} / 78-90$ & scalp & $\begin{array}{l}\text { Clobetasol and betamethasone } \\
\text { Topical antibiotics }\end{array}$ \\
\hline Patton et al. (2007) [13] & 11 & $\begin{array}{l}8 \mathrm{~F} / 66-90 \\
3 \mathrm{M} / 15-85\end{array}$ & $\begin{array}{l}9 \text { scalp } \\
1 \text { legs } \\
1 \text { upper extremity }\end{array}$ & $\begin{array}{l}\text { Clobetasol } \\
\text { Topical tacrolimus }\end{array}$ \\
\hline Ikeda et al. (1982) [14] & 1 & $\mathrm{~F} / 91$ & scalp & Oral zinc sulfate \\
\hline Lafitte et al. [15] & 2 & $2 \mathrm{M} / 55-65$ & scalp & $\begin{array}{l}\text { Clobetasol } \\
\text { Topical tacrolimus }\end{array}$ \\
\hline
\end{tabular}

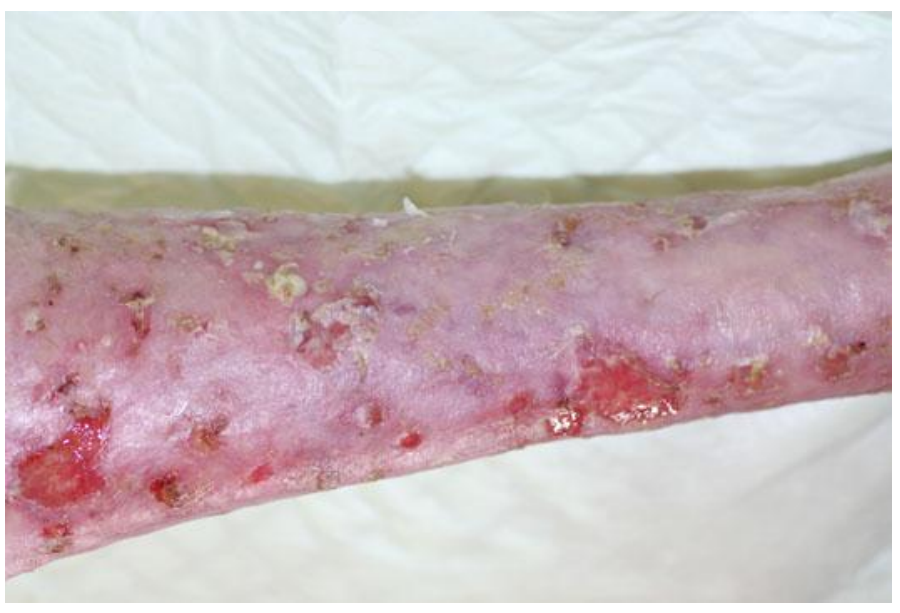

Fig. 1. The erythematous lower third of the leg covered with numerous superficial rounded crusted erosions and scattered pustules. 


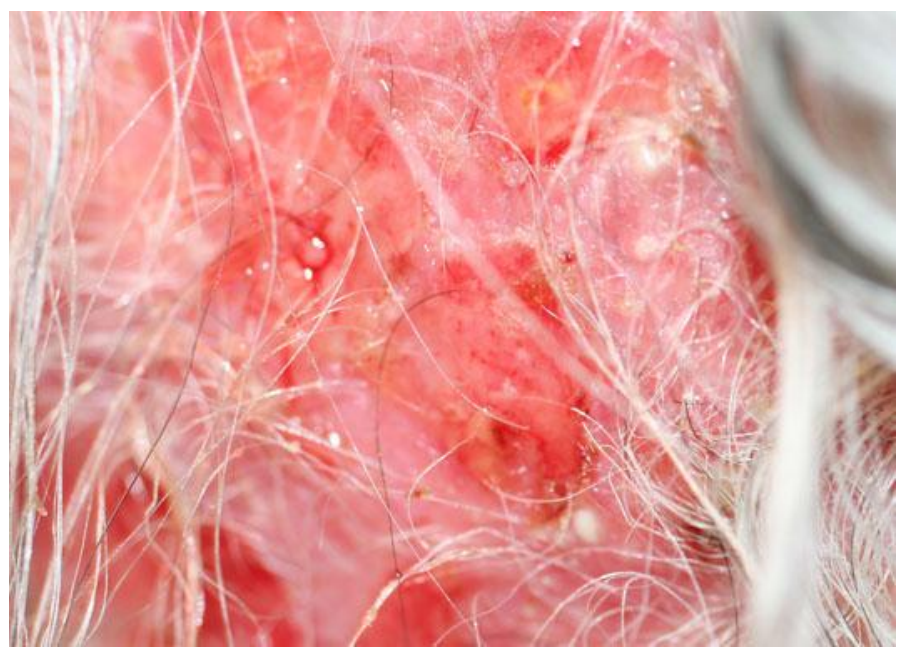

Fig. 2. Erosive crusted lesions on the scalp.

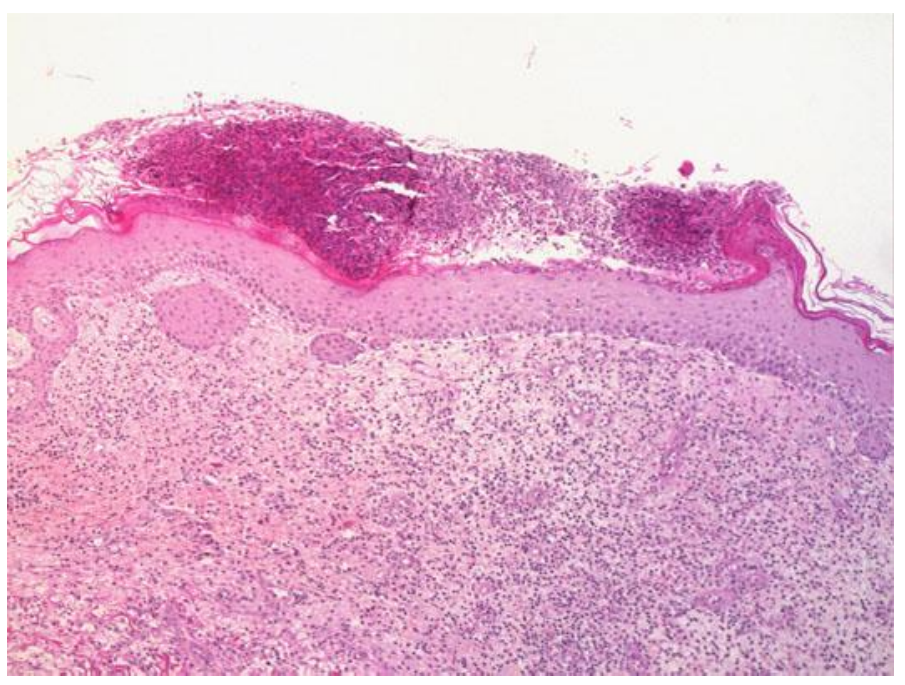

Fig. 3. Histological picture showing neutrophil infiltration in the dermis and invasion into subcorneal spongiform pustules.

\section{References}

1 Lanigan SW, Cotterill JA: Erosive pustular dermatosis - a common development in atrophic skin. Br J Dermatol 1987;117:15.

$\checkmark 2$ Cotterill JA, Lanigan SW: Erosive pustular dermatosis of the legs definition. Br J Dermatol 1990;123:548.

3 Brouard MC, et al: Erosive pustular dermatosis of the leg: report of three cases. Br J Dermatol 2002;147:765-769.

4 Sawada Y, Bito T, Kawakami C, Shimauchi T, Nakamura M, Tokura Y: Erosive pustular dermatosis of the scalp and leg associated with myasthenia gravis: a possible pathogenic role for neutrophil-stimulating cytokines and chemokines. Acta Derm Venerol 2010;90:652-653.

5 Burton JL: Case for diagnosis. Pustular dermatosis of scalp. Br J Dermatol 1977;97 Suppl 15:67-69. 
-6 Grattan CE, Peachey RD, Boon A: Evidence for a role of local trauma in the pathogenesis of erosive pustular dermatosis of the scalp. Clin Exp Dermatol 1988;13:7-10.

7 Rongioletti F, Delmonte S, Rossi ME, Strani GF, Rebora A: Erosive pustular dermatosis of the scalp following cryotherapy and topical tretinoin for actinic keratosis. Clin Exp Dermatol 1999;24:499-500.

$>8$ Guarneri C, Vaccaro M: Erosive pustular dermatosis of the scalp following topical methylaminolaevulinate photodynamic therapy. J Am Acad Dermatol 2009;60:521-522.

9 Watanabe S, Takizawa K, Hashimoto N, Ishibashi Y: Pustular dermatosis of the scalp associated with autoimmune diseases. J Dermatol 1989;16:383-387.

10 Yamamoto T, Furuse Y: Erosive pustular dermatosis of the scalp in association with rheumatoid arthritis. Int J Dermatol 1995;34:148.

11 Saurat JH, Borradori L, Harms M: Dermatoses neutrophiliques; in Saurat JH, Grosshans E, Laugier P, Lachapelle JM 3rd (eds): Dermatologie et maladies sexuellements transmissibles. Paris, Masson, 1999, pp 484-497.

12 Pye RJ, Peachey RDG, Burton JL: Erosive pustular dermatosis of the scalp. Br J Dermatol 1979;100:559566.

13 Patton D, Lynch P, Fung M, Fazel N: Chronic atrophic erosive dermatosis of the scalp and extremities: a recharacterization of erosive pustular dermatosis. J Am Acad Dermatol 2007;57:421-427.

14 Ikeda M, Arata J, Isaka H: Erosive pustular dermatosis of the scalp successfully treated with oral zinc sulphate. Br J Dermatol 1982;106:742-743.

15 Laffitte E, Kaya G, Piguet V, Saurat JH: Erosive pustular dermatosis of the scalp: treatment with topical tacrolimus. Arch Dermatol 2003;139:712-714.

16 Bonerandi JJ: Erosive and pustular scalp diseases. Ann Dermatol Venerol 1999;126:311-312. 